Swarthmore College

Works

History Faculty Works

History

Fall 1990

\title{
The Politicization Of Labor In 1905: The Case Of Odessa Salesclerks
}

Robert Weinberg

Swarthmore College, rweinbe1@swarthmore.edu

Follow this and additional works at: https://works.swarthmore.edu/fac-history

Part of the History Commons

Let us know how access to these works benefits you

\section{Recommended Citation}

Robert Weinberg. (1990). "The Politicization Of Labor In 1905: The Case Of Odessa Salesclerks". Slavic Review. Volume 49, Issue 3. 427-445. DOI: 10.2307/2499988

https://works.swarthmore.edu/fac-history/114

This work is brought to you for free by Swarthmore College Libraries' Works. It has been accepted for inclusion in History Faculty Works by an authorized administrator of Works. For more information, please contact myworks@swarthmore.edu. 
The Politicization of Labor in 1905: The Case of Odessa Salesclerks

Author(s): Robert Weinberg

Source: Slavic Review, Vol. 49, No. 3 (Autumn, 1990), pp. 427-445

Published by: Association for Slavic, East European, and Eurasian Studies

Stable URL: http://www.jstor.org/stable/2499988

Accessed: 08-04-2016 17:33 UTC

Your use of the JSTOR archive indicates your acceptance of the Terms \& Conditions of Use, available at

http://about.jstor.org/terms

JSTOR is a not-for-profit service that helps scholars, researchers, and students discover, use, and build upon a wide range of content in a trusted

digital archive. We use information technology and tools to increase productivity and facilitate new forms of scholarship. For more information about JSTOR, please contact support@jstor.org.

Association for Slavic, East European, and Eurasian Studies is collaborating with JSTOR to digitize, preserve and extend access to Slavic Review 


\section{The Politicization of Labor in 1905: The Case of Odessa Salesclerks}

One remarkable feature of the 1905 Russian Revolution was the efflorescence of labor organizations that occurred throughout the urban regions of the empire. Many workers throughout the empire demonstrated their resolve to promote and defend their interests in an organized and rational manner, with the mass labor movement often cutting across craft and occupational divisions to bring all kinds of workers into joint economic and political action against both employer and autocracy. As 1905 progressed the political radicalization of urban workers inspired much of the opposition movement that nearly brought the government to its knees. As several United States historians have recently shown, in 1905 organized labor, particularly trade unions, entered the political arena as a potent force, with workers simultaneously demanding individual rights of citizenship and collective rights of association. ${ }^{1}$

After 1905 Russian historians began debating the origins of trade unions in Russia. ${ }^{2}$ Bolshevik historians, following the lead set by Lenin, asserted that trade unions emerged from the strikes of 1905 and were partially rooted in the illegal strike funds set up under the direction of the Social Democrats. Other Russian historians, while not denying the importance of labor unrest and underground radical activity in fueling the emergence of trade unions, recognized that workers' experiences in other pre-1905 labor organizations were significant in union formation. Of particular importance to some of these historians was the specific role of mutual aid societies in the establishment of individual unions. Vladimir Sviatlovskii, a liberal professor at St. Petersburg

I would like to thank the Harriman Institute of Columbia University and its former assistant director, Jonathan Sanders, for providing the funding and congenial atmosphere that enabled me to write this article.

1. See especially Victoria E. Bonnell, Roots of Rebellion: Workers' Politics and Organizations in St. Petersburg and Moscow, 1900-1914 (Berkeley: University of California Press, 1983); Laura Engelstein, Moscow, 1905: Working-Class Organizations and Political Conflict (Stanford, Calif.: Stanford University Press, 1982); Henry Reichman, Railwaymen and Revolution: Russia, 1905 (Berkeley: University of California Press, 1987); Abraham Ascher, The Revolution of 1905: Russia in Disarray (Stanford, Calif.: Stanford University Press, 1988); Gerald Surh, 1905 in St. Petersburg: Labor, Society, and Revolution (Stanford, Calif.: Stanford University Press, 1989).

2. Among the better known works are D. V. Antoshkin, Professional'noe dvizhenie v Rossii, 3rd ed. (Moscow, 1925) and Ocherk dvizheniia sluzhashchikh v Rossii (so vtoroi poloviny XIX-go veka) (Moscow, 1921); V. V. Sviatlovskii, Professional'noe dvizhenie v Rossii (St. Petersburg, 1907) and "Iz istorii kass i obshchestv vzaimopomoshchi rabochikh," Arkhiv istorii truda v Rossii, vk. 4 (1922), 32-46; P. N. Kolokol'nikov and S. Rapaport, eds., $1905-1907$ gg. v professional'nom dvizhenii: I i II Vserossiiskie konferentsii professional'nykh soiuzov (Moscow, 1925); P. N. Kolokol'nikov, Professional'noe dvizhenie $v$ Rossii, vol. 1, Organizatsiia soiuzov (Petrograd, 1917); V. Grinevich, Professional'noe dvizhenie rabochikh $v$ Rossii (St. Petersburg, 1908); Iu. Milonov, Kak voznikli professional'nye soiuzy v Rossii, 2nd ed. (Moscow, 1929); S. S. Ainzaft, Pervyi etap professional'nogo dvizheniia v Rossii (1905-1907 gg.) (Moscow and Gomel, 1924); Professional'noe dvizhenie v Rossii v 1905-1907 gg. (Moscow, 1925); S. N. Prokopovich, K rabochemu voprosu v Rossii (St. Petersburg, 1905); V. Iarotskii, "Tezisy doklady," "Stenogramma diskussii," R. Iakub, "K voprosu ob 'istokakh' professional'nogo dvizheniia v Rossii," and S. Ainzaft, "Byli li kassy vzaimopomoshchi odnim iz istokov rossiiskogo professional'nogo dvizheniia," all in Materialy po istorii professional'nogo dvizheniia v Rossii (Moscow, 1924) 2:3-102. For a general discussion of the debate, see, S. N. Shchegolova, "Iz istoriografii profsoiuznogo dvizheniia v gody pervoi russkoi revoliutsii," in Revoliutsiia 1905-1907 godov v Rossii i profsoiuzy. (K 70-letiu pervoi russkoi burzhuaznodemokraticheskoi revoliutsii): Sbornik statei (Moscow, 1975), 118-143.

Slavic Review' 49, no. 3 (Fall 1990) 
University who figured prominently in the union movement in 1905, held that mutual aid societies were "the precursors of . . . the trade union movement." ${ }_{3}$ The debate reached its zenith in the 1920 s, when historians of both persuasions argued their positions in an atmosphere of relative intellectual freedom, but it ended abruptly with the ascendancy of Stalin and the adoption of a strict party line that stressed the role of strikes, Bolshevik agitation, and political conflict in the establishment of trade unions. In general, the debate ignored mutual aid societies as antecedents of the organized labor movement. This view has dominated most Soviet work on the subject since. ${ }^{4}$

Victoria Bonnell has resurrected the importance of mutual aid societies in illuminating the process of union formation in 1905. While not ignoring the determining influence of strikes and political developments as well as the legacy of Zubatovist and Gaponist unions in the establishment of unions in 1905, Bonnell stresses that many mutual aid societies, which were older, more numerous, and more geographically widespread than other legal labor organizations before 1905, either provided workers with exposure to, and practical expertise and experience with, labor organizations or were the institutional foundations of many trade unions formed in 1905. Moreover, many workers in 1905 demonstrated their interest in mutual aid even while they were involved in other forms of labor activism, including the establishment of trade unions. ${ }^{5}$ As Bonnell writes,

Mutual aid societies demonstrated the benefits of collective self-help as a means of defense against the depredations of the industrial age, an idea with wide appeal among workers who lacked government or employer assistance in the face of illness, accident, or other adversity. At the first opportunity to create massmembership organizations in 1905-1907, workers made the provision of mutual aid a paramount task. ${ }^{6}$

3. Sviatlovskii, "Iz istorii kass i obshchestv vzaimopomoshchi rabochikh," 46.

4. See, for example, Rabochii klass v pervoi rossiiskoi revoliutsii 1905-1907 gg. (Moscow, 1981), 256-262; Istoriia profsoiuzov SSSR, 2nd ed. (Moscow, 1977), pt. 1: 16-30; Kratkaia istoriia rabochego dvizheniia Rossii (1861-1917 gody) (Moscow, 1962), 355; Ocherki istorii professional'nykh soiuzov Ukrainskoi SSR (Kiev, 1983), 14-24; A. I. Priimenko, Legal'nye organizatsii rabochikh iuga Rossii v period imperializma (1895 g.-fevral' 1917 g.) (Kiev-Donetsk, 1977). Even the most prominent and sophisticated Soviet historian of the prerevolutionary Russian workers' movement scarcely mentions mutual aid societies in his most recent book: See Iu. I. Kir'ianov, Perekhod $k$ massovoi politicheskoi bor' be: Rabochii klass nakanune pervoi rossiiskoi revoliutsii (Moscow, 1987), 17 and 173. One Soviet historian who does not view pre-1905 legal labor organizations with a jaundiced eye and sees their importance in laying the groundwork for trade unions is A. V. Ushakov, "K voprosu o pervykh professional'nykh ob"edineniiakh rabochikh v Rossii," Rabochii klass i rabochee dvizhenie v Rossii v period imperializma (Moscow, 1978), 4-16.

5. Bonnell, of course, does not trace the 1905 explosion of union activity primarily to the heritage of mutual aid. Rather, she and other historians of the labor movement in 1905 emphasize that mutual aid and other previous labor associations helped pave the way for some of the workers' organizations that emerged in that year. Roots of Rebellion: Workers' Politics and Organizations in St. Petersburg and Moscow, 1900-1914, chap. 2 and passim. Laura Engelstein, Henry Reichman, and Tim McDaniel also devote attention to the connection between mutual aid societies (and other legal labor associations) and union formation in 1905 in their Autocracy, Captitalism, and Revolution in Russia (Berkeley: University of California Press, 1988). For other discussions of pre-1905 legal labor associations, see Gerald Surh, "Petersburg's First Mass Labor Organization: The Assembly of Russian Workers and Father Gapon," Russian Review, 40 (July 1981): 241-262 (part 1) and (October 1981): 412-441 (part 2); Jeremiah Schneiderman, Sergei Zubatov and Revolutionary Marxism: The Struggle for the Working Class in Tsarist Russia (Ithaca, N.Y.: Cornell University Press, 1970 and 1976); Walter Sablinsky, The Road to Bloody Sunday (Princeton, N.J.: Princeton University Press, 1976).

6. Bonnell, Roots of Rebellion, 80. 
Leaving aside significant differences between the structure, social composition, and objectives of trade unions and mutual aid societies, the crucial issue becomes, in the words of Sviatlovskii, "how the workers' movement made the quick transition from peaceful mutual aid societies into militant organizations . . . having as their aim the class struggle of the proletariat." 7 An examination of the Odessa Mutual Aid Society of Jewish Salesclerks during the first several months of 1905 reveals how a major segment of the work force in the Russian Empire's fourth largest city became politicized and used an existing employer-dominated and politically neutral workers' organization to establish a class-conscious trade union that challenged the traditional prerogatives of employer and government. The radicalization of Odessa salesclerks is explained as much by their experiences as workers aggrieved with an organization that purportedly represented their interests (but in reality did little to promote them) as by their harsh working and living conditions and the political crisis of 1905. In this article we can observe the political radicalization of an occupational group that is generally ignored by historians but whose activities suggest ways to understand the actions of other wage laborers in urban Russia. Furthermore, we will focus attention on Odessa, a city that has been slighted in favor of the two capitals.

Salesclerks may strike some readers as curious or even wholly inappropriate candidates for examination by a historian interested in the politicization of Russian labor in 1905. Although many historians would categorize salesclerks as low-level, whitecollar employees of the petite bourgeoisie, classifying the majority of salesclerks (or shop assistants) as manual workers is more appropriate for several reasons. First, shop assistants were distinguished from other sales-clerical personnel, such as cashiers, bookkeepers, and office clerks, by virtue of their relatively lower levels of education, skill, and training. Second, and more important, salesclerks devoted a significant portion of their workday to cleaning the store, running errands, delivering goods, and stocking shelves. Finally, salesclerks were often compelled to manufacture the goods they sold. Many owners of hat stores, for example, operated workshops that produced the caps and hats sold in their stores. Instead of hiring additional workers during busy periods, store owners cut production costs by having their clerks put on trim and lace and make alterations at no extra remuneration after a full day behind the sales counter. ${ }^{8}$

In 1901 Andrei Gudvan, the leading authority and defender of salesclerks' interests not only in Odessa but the empire as well, conducted a survey of shop assistants in the city's retail stores; he found that some 26,000 shop assistants were employed in the stores. The overwhelming majority were male, Jewish, and under thirty years of age; nearly 87 percent of the salesclerks could, to some extent, read and write, with onethird of all salesclerks having finished elementary school. Female salesclerks were mostly in the least-skilled and poorest paying positions. Females were also employed in fashionable pastry shops and bakeries where wages were nonetheless low. Clerks in retail stores were among the most exploited and abused workers in the empire. Like employees of workshops and small factories, as well as construction workers and day laborers, salesclerks were subject to the whims and fancies of employers who were not restricted by legislative rules and regulations regarding wages, hours, and other terms of employment. Indeed, until 1902 merchants (a social category that included store

7. Sviatlovskii, Professional'noe dvizhenie v Rossii, 50.

8. A. M. Gudvan, Prikazchichii vopros (Zhizn' i trud prikazchikov (Odessa, 1905), 55-56. 
owners) possessed the right to punish their young employees with a birch rod. Moreover, shop assistants did not have the option of instituting grievance proceedings with a factory inspector, a privilege enjoyed after 1901 by workers in manufacturing enterprises employing twenty or more workers. ${ }^{9}$

Most salesclerks eked out a miserable existence and endured physically and psychologically grueling work conditions. Shop assistants entered the labor force as apprentices, usually at age nine or ten, and were subjected to a regimen of work and discipline that could include work days of nineteen or twenty hours during which they cleaned the store, washed dishes, cooked meals, and performed all sorts of menial tasks for their employers. In short, the life of an apprentice salesclerk resembled that of a domestic servant. The young salesclerk, after three or four years of training, would be promoted to work behind the sales counter, but even then work continued to be physically demanding and exhausting. Working and living conditions among the city's retail clerks left much to be desired; nearly half of those surveyed lived in cold and damp basement apartments. In addition, salesclerks were often instructed to drum up business by standing in the street even in inclement weather and coaxing potential customers into the store. Teenaged or adult salesclerks in Odessa worked an average of fifteen to sixteen hours a day and were required to stand at all times, even if there were no customers. Gudvan found that nearly four-fifths of Odessa's shop assistants never enjoyed a formal lunch hour and ate standing behind the counter. In fact, they were usually forbidden to eat lunch off the store premises. Shop assistants generally had no full days off and worked 350 to 355 days a year. Just under half the surveyed salesclerks earned less than 20 rubles a month; female salesclerks earned on average less than half what men received. Some women claimed that they turned to prostitution to make ends meet and to afford the nice clothes they were required to wear in the fashionable shops and patisseries where they tended to work. ${ }^{10}$

Salesclerks were at the mercy of their employers, who often mistreated them and subjected them to verbal abuse. L. O. Karmen, in his study of Odessa salesclerks, recorded the story of one salesclerk who complained that his employer's wife had cursed him, yelling that he was "drinking her blood," because he drank tea with sugar. In another incident, a store owner refused a clerk's request for a pay raise by insisting that it was not his fault that the employee was experiencing difficulty supporting his family. The employer shouted, "didn't I tell you not to marry? A poor salesclerk should not and does not have the right to marry." "I

In the decade or so before 1905 attempts were made to ameliorate the salesclerks'

9. Approximately 33,000 sales-clerical workers (shop assistants, bookkeepers, cashiers, clerks, and other office workers) worked in Odessa at the turn of the century, but we are concerned here with those employed in retail stores as shop assistants. The results of the survey can be found in A. M. Gudvan, Prikazchiki v Odesse (Odessa, 1903). Between 1886 and 1901 the Factory Inspectorate had jurisdiction over workers in manufacturing enterprises ("factories") that employed fifteen or more workers or used enginedriven equipment; in 1901 the government changed the definition of a factory to include manufacturing enterprises with twenty or more workers regardless of the type of machinery used.

10. Information on the working and living conditions of Odessa salesclerks is taken from Gudvan, Prikazchiki v Odesse, passim; idem, Prikazchichii vopros (Zhizn' i trud prikazchikov, passim, Ocherki po istorii dvizheniia sluzhashchikh v Rossii, part 1. Do revoliutsii 1905 goda (Moscow, 1905), passim. Selections from the last can be found in Victoria Bonnell, ed., The Russian Worker: Life and Labor under the Tsarist Regime (Berkeley: University of California Press, 1983), 186-208. See also Voskhod, no. 6, 12 February $1904,8-13$.

11. L. O. Karmen, Zhizn' odesskikh prikazchikov (Odessa, 1903). These Dickensian horrors are supported by evidence furnished by Gudvan. See his Ocherki po istorii, chap. 6. 
situation by extending legislative protection to them. Mutual aid societies of salesclerks throughout the empire addressed to various city councils and the Ministry of Finance a series of petitions calling for standardization of the working hours of salesclerks. Some merchants and store owners in Odessa and other cities, perhaps guided more by a concern for profits and productivity than by humanitarian instincts, took up their employees' cause and voluntarily restricted hours of operation on Sundays and holidays. Odessa was one of the few cities where the city fathers and merchants tried to improve working conditions for salesclerks, but the city council's measures were piecemeal, half-hearted, and virtually unenforceable. For example, compliance with the municipal regulation limiting retail stores' hours of operations to four hours on Sundays and nine on holidays was easily avoided, especially if the store was in an outlying district. The movement to normalize the workday of salesclerks through legislation and goodwill failed to achieve its intended aims, largely because the central government and local municipalities never committed themselves to such a policy and not all merchants and store owners complied with the self-imposed restrictions. ${ }^{12}$

In early 1905, salesclerks, frustrated with the failure of existing paternalistic policies to bring about substantive changes in working conditions and caught up in the highly charged political atmosphere of Russia's first revolutionary crisis, began to adopt a more militant and activist stance. They embraced a strategy that challenged the economic and political status quo and broke with the traditional autocratic pattern of labor relations among workers, employers, and government. Examination of the shop assistants' experiences with one of the mutual aid societies purporting to represent their interests - the Odessa Mutual Aid Society of Jewish Salesclerks-will be helpful in illustrating this shift in the salesclerks' stance. The activities of this organization and the clerks' relations to it helped shape the political behavior of the workers. First, however, we must explore mutual aid societies in Odessa.

Restrictive government policies regarding voluntary association stunted civil society in imperial Russia and the formation of mutual aid societies. Mutual aid societies had emerged among teachers, workshop employees, salesclerks, factory workers, and other wage laborers during the nineteenth century. These organizations did not address issues of wages, hours of work, and other working conditions but, like their counterparts in western Europe, primarily provided sickness, accident, and funeral benefits. Many mutual aid societies also offered material assistance to widows and orphans of deceased members, cultural and educational activities, educational expenses for orphans, unemployment benefits, and legal assistance. The societies included either workers of a given occupation or employees of an individual enterprise; in both instances, however, membership usually was not limited to employees; employers, supervisory personnel, and even prominent members of the community could, and did, join. In general, employers controlled the affairs of most societies by dominating their elected governing boards. ${ }^{13}$ Mutual aid societies lacked the notion of an adversarial

12. On the movement to standardize the workday of salesclerks through petitions, legislation, and voluntary compliance, see Gudvan, Prikazchiki v Odesse, 47-55; idem, Ocherki po istorii, 199-226; idem, Prikazchichii vopros, 14-20; Trudy pervago s"ezda predstavitelei obshchestv vspomozheniia chastnomu sluzhebnomu trudu (Nizhnii Novgorod, 1897), passim; Trudy vtorago s"ezda predstavitelei obshchest vspomozheniia chastnomu sluzhebnomu trudu (Moscow, 1900), passim.

13. See Bonnell, Roots of Rebellion, 76-80; Gudvan, Ocherki po istorii dvizheniia sluzhashchikh v Rossii, 62-95, and the works cited in note 2 above for a general treatment of mutual aid societies in pre-1905 Russia. 
employee-employer relationship, the essence of trade unionism; in fact, the interests of their governing boards tended to coincide with those of the retailers and shopkeepers. The paternalism of mutual aid societies was well suited to labor relations in late imperial Russia, where workers lacked collective bargaining rights and policy makers refused to sanction independent labor organizations until 1906.

The first mutual aid society in Odessa emerged among printers in 1816. How long this association existed is not known but, since printers established another mutual aid society in 1884 , the original association probably had ceased to exist before this date. In the 1860 s both Jewish and Christian salesclerks formed separate mutual aid societies that operated through 1905. Bonnell suggests that printers and salesclerks were consistently among the first to establish mutual aid societies because a mix of job status, skill, literacy, and urbanization "rendered them exceptionally well suited to the tasks of collective organization." ${ }^{14}$ Yet other workers, who did not enjoy the same mix of job characteristics, also participated in mutual aid societies. In 1881, for example, a group of waiters in Odessa established a mutual aid society, and in 1886 quarry workers, aided by their employers, also created a similar association. Sailors of the various shipping lines in Odessa also began a mutual aid society "to improve the material conditions of workers of the merchant marine of the Black and Azov seas." 15

By the turn of the century mutual benefit associations existed among workers of various crafts: housepainters, woodworkers, shoemakers, bootmakers, and tailors. Similar associations also existed at the enterprise level; workers at the Pekatoros Leather Factory established a fund to assist members during illness. ${ }^{16}$ Unfortunately, the number of workers who joined mutual aid societies is difficult to ascertain. The fact that many members of the associations were not employees but employers and other prominent members of Odessa society, such as the city governor, wealthy merchants, and philanthropists who were corresponding or honorary members with the right to hold office and vote, compounds this problem and suggests that the number of actual workers belonging to these organizations was lower than indicated by the sparse data regarding membership totals. ${ }^{17}$

One factor accounting for workers' low participation in mutual aid societies was undoubtedly the steep cost of entry fees and monthly dues. This factor was especially important for salesclerks and probably for workers in other occupations as well. In the Odessa Mutual Aid Society of Jewish Salesclerks (OMASJS), for example, the "aristocrats" of the sales-clerical occupation (male office workers, bookkeepers, cashiers, and clerks) made up the overwhelming majority of members because the organization excluded women and deliberately set the entry fee and dues at levels beyond the financial means of the average shop assistant. Cost was one element of the strategy adopted by the association to restrict membership to the elite of salesclerks. The Odessa Mutual Aid Society of Printers also attracted the most highly skilled and well-paid members of

14. Bonnell, Roots of Rebellion, 76; Kolokol'nikov and Rapoport, eds., 1905-1907 gg. v profesional'nom dvizhenii, 126; Ocherk deiatel'nosti Odesskago obshchestva vzaimnago vspomoshchestvovaniia prikazchikov-evreev za 50 let (Odessa, 1913), 5; Iuzhno-russkii al'manakh (1897), 183.

15. Sviatlovskii, "Iz istorii kass i obshchestv vzaimopomoshchi rabochikh," 38; Prokopovich, $K$ rabochemu voprosu, 19; Otchet Odesskago obshchestva vzaimopomoshchi moriakov torgovago flota za 1904-1905 gody (Odessa, 1906), 19.

16. Kommercheskaia Rossiia, no. 43, 15 February 1905; Iskra, no. 55, 15 December 1903.

17. The historian Simon Dubnow and political activist Vladimir Jabotinskii also belonged to the Odessa Mutual Aid Society of Jewish Salesclerks. 
the trade-typesetters, lithographers, engravers, and typefounders-through high dues and fees; these skills made up most of that association's membership. ${ }^{18}$

Employers and managers commonly participated in mutual aid societies in Odessa and dominated the affairs of the organizations. Not only were owners and supervisors elected to key offices on the administrative boards of mutual aid societies but in some instances they even helped to form associations. In 1886, for example, when workers and owners jointly petitioned the city governor for permission to establish a mutual aid society of quarry workers, the owners of the stone quarries even volunteered to pay both the entry fees and part of the weekly dues of each member. ${ }^{19}$ Since authority was vested in governing boards that were dominated by employers, workers exercised little control over the actions and policies of the societies. In 1894 or 1895 a delegation of woodworkers, for instance, presented a charter for a projected mutual aid society to the Odessa factory inspector, who said he would support the workers' petition only if the owners of the woodworking workshops were granted control of the governing board..$^{20}$

Even though worker contributions funded the treasuries, the governing boards determined who was eligible for assistance and the amount an individual was to receive. Workers often resented this state of affairs, especially when benefits were insufficient or not forthcoming. In 1903 workers at the Pekatoros Leather Factory protested the owner's decision to withhold payment of sickness benefits to members of the enterprise's mutual aid society. The director of the factory told workers, "the treasury is not yours, but the company's." ${ }^{21}$ Given their lack of civil and legal rights, the aggrieved leather workers could only bristle at the insult.

All these features of mutual aid societies in Odessa and elsewhere characterized, to one degree of another, the Odessa Mutual Aid Society of Jewish Salesclerks. At the turn of the twentieth century five mutual aid societies of salesclerks and office workers existed in Odessa; in addition to separate organizations of Jewish and Christian salesclerks, expediters at the Customs House, merchants' agents, and such office workers as bookkeepers and clerks belonged to their own mutual benefit associations. Such fragmentation was typical of salesclerk labor activism throughout Russia. In 1898 around 100 mutual aid societies of salesclerks existed in European Russia; they claimed some 20,000 members. ${ }^{22}$ The OMASJS had the largest membership of all the mutual benefit societies in Odessa, with 800 in 1898; the Christian-based association claimed 531 members. By contrast, the Odessa Mutual Aid Society of Printers had only 97 members during the first half of the $1890 \mathrm{~s}^{23}$

In imperial Russia Jews commonly established networks of self-regulating institutions concerned with religious, professional, welfare, educational, and charitable issues. Each such organization, known as a hevrah (the Hebrew word for association),

18. Ocherk deiatel'nosti Odesskago obshchestva vzaimnago vspomoshchestvovaniia prikazchikovevreev za 50 let, 12 and 14; Otchet pravleniia obshchestva vzaimnago vspomozheniia truzhenikov pechatnago dela g. Odessy za 1890-91 gody (Odessa, 1892), 6.

19. Sviatlovskii, "Iz istorii kass i obshchestv vzaimopomoshchi rabochikh," 38.

20. Rabochee dvizhenie v Odesse (1894-1896 gody) (Geneva, 1903), 21.

21. Iskra, no. 55, 15 December 1903.

22. These data do not include Poland, the Baltic states, or Finland (Gudvan, Ocherki po istorii dvizheniia sluzhashchikh $v$ Rossii, 70-71)

23. Iuzhno-russkii al'manakh (1899), 68-69; Otchet pravleniia obshchestva vzaimnago vspomozheniia truzhenikov pechatnago dela g. Odessy za 1890-91 gody, 6. 
exemplified the cohesiveness of the Russian-Jewish community and promoted the interests of its membership. A hevrah generally included people of one occupation or everyone in the congregation of a specific synagogue or prayer house. The hevrah based on occupation tended to resemble a guild, whereas the devotional hevrah provided spiritual direction to its members and served as a community center. ${ }^{24}$ Since workers in the same occupation tended to attend the same synagogue or prayer house, even the devotional hevrah often assumed the character of a mutual aid society to benefit workers of a specific trade or occupation rather than to serve the congregation. The OMASJS was an outgrowth of the hevrah established by Jewish shop assistants who attended the Poele Emuna [faithful workers] prayer house.

In the early 1860 s a group of young Jewish salesclerks, frustrated with the unwillingness of the hevrah to provide material assistance in times of need and illness, decided that the religious orientation of the Poele Emuna hevrah did not adequately serve their interests as workers ${ }^{25}$ As the idea of establishing a special organization that would serve the interests of all salesclerks gradually gained popularity, shop assistants belonging to Poele Emuna began collecting money to fund an organization devoted solely to the needs and interests of salesclerks. Whether the new association should be attached to the hevrah and prayer house or organizationally independent was discussed. Some hevrah members struggled to maintain an organizational connection between the prayer house and the budding mutual aid society, but the majority of salesclerks believed that the limited aims and resources of the hevrah could not satisfy the needs of the rapidly expanding number of salesclerks.

The OMASJS began operations in March 1863 and, though no copy of its charter has survived, we know the new organization aimed to furnish mutual aid to all shop assistants and to assist members in finding employment. The society furnished loans, pensions, medical assistance, and death benefits and even provided stipends for the education of members' children. The governing board requested that merchants and store owners notify it of job vacancies and established a list of unemployed salesclerks from which it selected eligible candidates for these openings. Many Jewish salesclerks actively participated in the formulation of society policy.

In the $1880 \mathrm{~s}$, however, the organization began to lose its democratic character and popular foundations because of the changing social composition of its membership. By the early 1880 s many original members had become independent shop owners and employers of labor. Hard data are lacking, but the proportion of members who were salesclerks declined relative to the growing number of employers and others who were not salesclerks (including grain brokers, doctors, lawyers, and even engineers) whose money and influence enabled them to assume control of the organization. For example, Samson Bernfel'd, a salesclerk who played a critical role in the establishment of the

24. For a general overview of the hevrah, see Isaac Levitats, The Jewish Community in Russia, 1772-1844 (New York: Columbia University Press, 1943), 105-122 and passim; and idem, The Jewish Community in Russia, 1844-1917 (Jerusalem: Posner, 1981), 69-84; Sviatlovskii, "Iz istorii kass i obshchestv vzaimopomoshchi rabochikh," 32-33; and idem, Professional'noe dvizhenie v Rossii, 23-25; Prokopovich, K rabochemu voprosu, 3-7; Sara Rabinowitsch, Die Organizationen des jüdisches Proletariats in Russland (Karlsruhe, 1903), passim.

25. Material in the following paragraphs is based on Ocherk deiatel'nosti Odesskago obshchestva vzaimnago vspomoshchestvovaniia prikazchikov-evreev za 50 let, 5-14; Obzor deiatel'nosti Odesskago obshchestva vzaimnago vspomoshchestvovaniia prikazchikov-evreev za 35 let (Odessa, 1898), 10-11; Odesskii vestnik, no. 30, 29 June 1863, 317-318. 
society and served as its first president, had become a wealthy merchant by the 1880 s but retained his position in the organization. Grigorii Tarnopol, who had begun as a bookkeeper but became a successful industrialist after opening a factory with his brother David, succeeded Bernfel'd as president of the mutual aid society. ${ }^{26}$

The policies of the governing board reflected this transformation in the society's membership. Entry fees and dues were increased to convert the organization into a preserve of employers and elite workers of the sales-clerical occupation. As more members began to join the ranks of the propertied class and to acquire wealth, the society began to ignore the needs and interests of the average salesclerk, and the OMASJS became isolated from its original constituency. From the 1880s, the chief beneficiary of the mutual aid society was that small minority of salesclerks who could afford the fees and dues and meet the other strict membership requirements of the governing board. That the organization boasted a little more than one thousand members in early 1900, and that not all of them were salesclerks, underscores its selective admissions policy and suggests why it tended to neglect the concerns of the typical shop assistant. ${ }^{27}$ Board members were more interested in the display of wealth (such as building an elaborate auditorium) and programs of enlightenment and culture than in promoting the economic concerns of salesclerks. After the turn of the century the organization did very little to improve working conditions for shop assistants or even to provide traditional sickness and death benefits. This development was not unique; the mutual aid society catering to Christian shop assistants, which emerged at the same time as did the OMASJS, also suffered from elitism and isolation from the rank and file. As the authors of a history of the OMASJS concluded, the organization had "barricaded itself in every possible way" from the average salesclerk..$^{28}$

The OMASJS played a significant role in the general cultural life of Odessa, however. The association's library had the second largest collection of books and periodicals in Odessa, with exceptionally rich holdings on Jewish philosophy, ethics, history, and religion in Hebrew, Russian, and German. Borrowers were especially interested in belles lettres and read works by Lev Tolstoi, Anton Chekhov, Fedor Dostoevskii, Maksim Gorki, Emile Zola, Charles Dickens, Victor Hugo, and Henrik Ibsen. They also enjoyed such liberal to left periodicals as Mir Bozhii, Russkaia mysl', and Russkoe bogatstvo. In addition, the society held concerts, theatrical performances, lectures, and public readings in its elaborate building. ${ }^{29}$

As a consequence of the neglect of salesclerks' economic interests, divisiveness and confrontation more and more characterized the affairs of the OMASJS after the turn of the century. Though evidence on these developments is fragmentary and scat-

26. G. A. Tarnopol, Ocherk ego deiatel'nosti kak predsedatela, obshchestva vzaimnago vspomoshchestvovaniia prikazchikov-evreev g. Odessy (Odessa, 1890).

27. There were 873 full members, 114 corresponding members, and 17 honorary ones. The precise number of members who were not salesclerks cannot be determined. Otchet pravleniia Odesskago obshchestva vzaimnago vspomoshchestvovaniia prikazchikov-evreev za 1904 (Odessa, 1905), 11-12.

28. Ocherk deiatel'nosti Odesskago obshchestva vzaimnago vspomoshchestvovaniia prikazchikovevreev za 50 let, 14.

29. Iuzhno-russkii al'manakh (1897), 183; Budushchnost', no. 13, 30 March 1901, 243-245; Voskhod, no. 20, 16 May 1902, 23-27; Otchet pravleniia Odesskago obshchestva vzaimnago vspomoshchestvovaniia prikazchikov-evreev za 1903 g. (Odessa, 1904), 24-27; Otchet pravleniia Odesskago obshchestva vzaimnago vspomoshchestvovaniia prikazchikov-evreev za $1904 \mathrm{~g} ., 4$. 
tered, existing materials suggest that organizational fissures began to appear several years before 1905, with an emerging splinter movement challenging the OMASJS leadership. In 1903 a group of Odessa salesclerk activists, angry at the mutual aid societies' lack of concern, began to complain and voice its grievances. Some of these activists, particularly Moisei S. Kleiner, an office worker and member since 1892, participated actively in the affairs of the organization and suggested that the OMASJS establish closer ties with the rank and file. These activists succeeded in replacing several long-term members of the board of directors with men who were pledged to represent the interests of the typical salesclerk. As a result, the initiation fee and monthly dues were reduced.

Moreover, Social Democratic and Socialist Revolutionary agitators and organizers, who had been devoting attention to salesclerks in the city since the turn of the century, stepped up their activities by addressing leaflets and proclamations to them and successfully organizing small numbers of shop assistants. The socialists even advised and cooperated with Gudvan in the petition campaign to achieve legislation regulating work hours of salesclerks. In early 1903 Odessa Social Democrats organized an illegal union among the rank and file commercial and industrial employees without regard to sex and nationality and used it as a base for establishing ties with sales-clerical workers in other cities of southern Russia. In other cities reformers also challenged the power of employers, who controlled the mutual aid societies, and revolutionaries tried to recruit shop assistants. ${ }^{30}$

Odessa salesclerks, frustrated with the OMASJS, began to search for alternative solutions to their problems. The highly charged political atmosphere of 1905 , however, brought to a head the conflict between the rank and file salesclerks and those who purported to represent their interests in the mutual benefit associations. In 1905 salesclerks and reform-minded activists began to seek more radical outlets for their grievances.

The radicalization of Odessa salesclerks occurred in the period after Bloody Sunday when labor organizing accelerated; worker representatives were elected to sit on various government boards that investigated the causes of labor discontent and unrest. For the first time in the history of the Romanov dynasty the country was bristling with the excitement and exhilaration of independent activity by social groups that had never expressed themselves politically and were now trying to change matters of immediate concern to themselves. The extent of this political awakening can be gleaned from the page of Kommercheskaia Rossiia, a local newspaper that in the spring of 1905 was a forum in which workers debated the relevant social, economic, and political issues of the day.

Reflecting the budding political opposition movement among industrialists and merchants, the editorials of Kommercheskaia Rossiia, beginning in 1905, acquired a distinctly liberal slant, with a conciliatory attitude toward labor. According to a midMarch editorial the newspaper wanted to develop Russia's economic forces. A strong economy required "stable and just relations between workers and employers" and "re-

30. Information on these events and developments is extremely scarce, and memoir literature and published documents reveal little. Ocherk deiatel'nosti Odesskago obshchestva vzaimnago vspomoshchestvovaniia prikazchikov-evreev za 50 let, 14; Gudvan, Ocherki po istorii dvizheniia sluzhashchikh v Rossii, 87-95, 202-204, and 207-208; I. Lupinskii, "Soiuz prikazchikov Odessy (1905-1907 g.)," in Professional'noe dvizhenie sluzhashchikh Ukrainy (1905-1907 gg.), ed. I. S. Stepanskii (Kharkov, 1927), 65-67, 76 and 85-90; Otchet pravleniia Odesskago obshchestva vzaimnago vspomoshchestvovaniia prikazchikov-evreev za 1903, 15. 
spect for labor" on the part of employers. ${ }^{31}$ Thus, the first step in solving the labor problem was to permit the formation of trade unions to reach agreements with employers over working conditions and to help regulate the internal order of enterprises. Another editorial, written two weeks earlier, suggested that unions provide a forum from which workers could influence conditions of work and begin to influence decisions about factory life. ${ }^{32}$

In late winter the newspaper began publishing articles and letters written by workers. The pages of Kommercheskaia Rossiia from mid-February to the end of March are filled with workers' accounts of realizing that their economic woes were linked to the economic and political structure of Russian society. Some of the letter writers even advocated that workers take matters into their own hands and pursue a course of direct action designed to alter the existing socio-economic and political order, since they could not wait for the government to take appropriate action. Such an outpouring of worker discontent was unprecedented in Odessa, and its public expression is attributable to the relatively lax efforts of censors after Bloody Sunday.

Kommercheskaia Rossiia offers the best, if not the only, glimpse into this process of radicalization. ${ }^{33}$ Letters to Kommercheskaia Rossiia from Odessa salesclerks mark the beginning of public debate among workers and intellectuals on the value of trade unions and the role of politics and socialism in the labor movement. Since the majority of Odessa's shop assistants was ignored by existing mutual aid societies, they did not turn to these organizations for direction and guidance in the struggle for improved working conditions. By 1905 a movement to reform the OMASJS from within or to supplant it with a more democratic organization had existed for several years.

By early 1905 reports in Kommercheskaia Rossiia indicated that many young members of the OMASJS had concluded that a new organization, including as many salesclerks as possible without distinction of age, sex, and religion, should be established. These reformers argued that it was "the moral responsibility" of the existing mutual aid society to provide initiative, advice, and financial backing for the new organization. Despite the efforts at change implemented by the activists who had secured leadership posts in 1903, these reforming salesclerks condemned attempts at internal transformation of the direction and policies of the existing mutual aid society. They insisted that the current board of directors and membership were guilty not only of ignoring problems confronting the mass of Jewish salesclerks, but also of indifference toward their own organization and their responsibilities toward it. The principal spokesman of these reformers, known by the initials K. M., cited the fact that the OMASJS board of directors met only once or twice a year - usually without a quorum-as evidence that the current leadership could not be relied upon to undertake substantive reforms and to promote the interests of the average salesclerk. K. M. blamed this state of

31. Kommercheskaia Rossiia, no. 69, 14 March 1905.

32. Kommercheskaia Rossiia, no. 55, 27 February 1905.

33. Information about the activities of the OMASJS and salesclerks is hard to obtain because sources are unavailable. Reference to the actions and statements of salesclerks at meetings and assemblies would provide a rich view of the dynamics of grass roots organizing and mobilizing during 1905, but materials for such a discussion do not exist. We must depend on the letters and articles published in Kommercheskaia Rossiia to gauge the attitudes, sentiments, and opinions of Odessa salesclerks in 1905. While some would argue that the reporting in the liberal-leaning paper is biased and selective, the articles and letters do cover a broad spectrum of positions and outlooks. Moreover, the actions of salesclerks during 1905 bear out the conclusions drawn from the articles and letters in the paper. 
affairs on the membership that had failed to elect new board members, thereby indicating their acceptance of the status quo. A new society representing the interests of typical salesclerks would, K. M. held, enjoy broad support and loyalty. ${ }^{34}$

Despite its appeal for a more broadly based organization of salesclerks, K. M.'s proposal emphasized the traditional functions of mutual aid societies. The proposed organization was not innovative in goals and objectives: Its primary purpose remained providing death benefits, loans, insurance, and intellectual and cultural activities for members and their families. K. M. was clearly not advocating the establishment of a trade union that would seek material concessions from management by striking and demanding collective bargaining rights. K. M.'s reform proposed elimination of employer influence in administrative affairs of the society and establishment of a mediation process to resolve labor disputes. ${ }^{35}$

Not all salesclerks supported this proposal. Conceding that the existing organization did not serve the interests of most shop assistants, some other salesclerks stressed that formation of a new mutual aid society would divide rather than unify shop assistants. This group of workers, led by Moisei Kleiner, argued that changing the current policies of existing societies, which already possessed the institutional framework and material foundations, would more closely serve the interests and needs of salesclerks. A Socialist Revolutionary who in 1903 had suggested opening up membership of the OMASJS to all shop assistants, Kleiner, despite his political predilections, preferred to continue his reform activities within the existing organization. ${ }^{36}$ In addition some salesclerks condemned mutual aid as an outdated concept and advocated more radical solutions to the problems facing salesclerks; they called for forming a trade union and becoming involved in politics, preferably with a socialist slant.

Two editorials in Kommercheskaia Rossiia set the tone of an ensuing debate among salesclerks. On 8 and 13 March the paper's editors declared that before salesclerks-or any workers for that matter-attempted to achieve the ideal goal of "one large workers' party," they first needed to pass through several preliminary stages, such as the establishment of labor organizations based on occupation and locale. According to the editors, unions provide the fundamental solidarity and "discipline of mind and heart" upon which all other forms of workers' organizations, including political parties, are based. They cautioned the salesclerks to maintain organizational independence from all other labor groupings and political parties because this independence was the only guarantee against the centralizing tendencies inherent in a workers' party. ${ }^{37}$

Some salesclerks welcomed the idea of forming a trade union geared only to obtainiıg improved working conditions through collective bargaining and strikes, but more radical shop assistants condemned the editorials for overlooking the importance of politics and class struggle in the salesclerks' effort to achieve better lives. In a letter published on 30 March, one such radical accused the editors of Kommercheskaia Rossiia of focusing on narrow professional interests, an approach that this radical be-

34. Kommercheskaia Rossiia, nos. 11, 13 January 1905; 14, 16 January 1905; and 17, 19 January 1905. See also Kommercheskaia Rossiia, no. 12, 14 January 1905, and no. 56, 1 March 1905, Odesskie novosti, no. 6917, 20 April 1906.

35. Kommerchskaia Rossiia, nos. 14, 16 January 1905; 109, 5 May 1905; and 130, 31 May 1905.

36. Ibid., no. 13, 15 January 1905; Ocherk deiatel'nosti Odesskago obshchestva vzaimnago vspomoshchestvovaniia prikazchikov-evreev za 50 let, 15; Lupinskii, "Soiuz prikazchikov Odessy," 74; Odesskie novosti, no. 6934, 21 May 1906.

37. Kommercheskaia Rossiia, nos. 63, 8 March 1905, and 68, 13 March 1905. 
lieved obscured the salesclerk's vision that "he is not only a salesclerk but also a citizen . . . who does not enjoy the rights of citizenship." The radicals urged salesclerks to join other workers in a campaign for basic civil rights and a constituent assembly, without which the pursuit of economic improvements would be futile. The article proclaimed salesclerks to be "part of the proletarian army" and advised them to form a trade union to defend their "interests not only as salesclerks, since their social conditions make them proletarians." 38

One radical salesclerk, D. O-kii, in a series of articles with distinctly socialist tones, held that political neutrality among trade unions deprived workers of an understanding of the social and economic forces ruling their lives. He challenged the contention of the editors of Kommercheskaia Rossiia that a trade union that limited its activities to purely economic issues could achieve substantial improvements in the well-being of its members. O-kii did not distinguish between the kind of trade unions advocated by the newspaper and mutual aid societies: Both forms of organization, in his eyes, were interested only in achieving "temporary and transitory" economic successes within separate enterprises and thereby accepted the salesclerks' status as a "seller of labor on the market of a capitalist society." He faulted his opponents for not considering social issues and not recognizing that capitalism limits the improvements salesclerks can achieve. In his words, "there is a limit to how much salesclerks can gain by operating within a bourgeois society: there is a limit to improvements that can be achieved." ${ }^{39}$

Other salesclerks wrote letters that shared O-kii's anticapitalist and socialist leanings. They supported his views that improvements within the existing socio-economic order were mere palliatives and that only the transformation of the contemporary order would lead to lasting benefits for salesclerks. One salesclerk asserted that workers were ready to resolve their problems by themselves because they could not wait for society and government to take necessary action, while still another argued that "exploitation by capital" was the root of the salesclerks' hardships. The "problem of class" concerned all workers, according to this salesclerk, and required a labor party since unions were "too narrowly focused to deal with the real cause of exploitation." Yet another wrote that "the salesclerk is not only a clerk but a citizen as well. If he doesn't enjoy rights of citizenship, then he should achieve them. Along with other workers he should strive for basic freedoms of speech, print, conscience, unions, and strike." 40

Salesclerks and other workers were learning a basic lesson in 1905: The granting of significant political reforms, especially the right to assemble and organize without government or employer interference, was necessary if workers were to attain and preserve improved working conditions. Political liberation became an integral element in labor's struggle to achieve economic improvements and workers acknowledged the intimate connection between material gains and civil liberties, between the economic and political struggles. Whether the typical salesclerk shared (or understood) the class analysis expressed in these letters or possessed a proletarian identity is unknown. The behavior of the rank and file salesclerks for the remainder of 1905, however, indicates that the message of O-kii and others struck a responsive chord and spoke to the interests of the typical shop assistant.

38. Ibid., no. 84, 30 March 1905.

39. Ibid., nos. 61, 6 March 1905, and 66, 11 March 1905.

40. Ibid., nos. 58, 3 March 1905; 63, 8 March 1905; 71, 16 March 1905; 84, 30 March 1905; and 102, 26 April 1905. See also the letter from an unemployed salesclerk who stresses that shop assistants must unite with other workers and struggle to liberate themselves from the "oppression of exploitation" since they, like all proletarians, sell their labor (ibid., no. 126, 25 May 1905). 
Were any of these salesclerks affiliated with, or under the sway of, revolutionaries active in Odessa? No evidence indicates how many salesclerks had contact with revolutionaries, let alone how many participated in radical political activities and organizations. Not only had socialist agitators been active among Odessa's salesclerks for several years, but, in addition, several leaders of the salesclerks' union formed in late 1905 were socialists. This state of affairs parallels the salesclerks' experience in Moscow, where union leaders favored the Mensheviks, and St. Petersburg, where the Bolsheviks were favored. Yet exposure and contact does not necessarily translate into control and direction, and caution is required when drawing conclusions about the political allegiances of rank and file shop assistants. The leaders of the salesclerks' union probably occupied their positions because of their status among their constituency and their organizational experience and expertise, not because they espoused specific political platforms. Kleiner, who advocated internal reform of the OMASJS, continued his affiliation with the mutual aid society even after a Union of Salesclerks emerged in late 1905. In fact, he represented the OMASJS at the Third All-Russian Congress of Mutual Aid Societies of Salesclerks in $1906 .{ }^{41}$ We are attracted to a conclusion drawn by Gudvan in early 1905 that Odessa salesclerks were politicized not by the machinations of revolutionaries but through the actions of bureaucrats who failed to standardize hours of work and to prevent other abuses of shop assistants. ${ }^{42}$ In the first half of 1905 , Odessa salesclerks displayed a highly politically attuned awareness of the problems confronting workers. This fact does not mean, however, that they were acting under the tutelage, let alone direction, of revolutionary socialists.

Many salesclerks had undoubtedly come to realize that the hope of opening their own stores was now a pipe dream. In the words of one N. Lialich, shop assistants now had "no exit" from their situation as hired hands who must "defend their class interests" in relation to the store owners. Before 1905, retail firms that used large amounts of capital and labor had begun to outcompete small store owners and to cause the further deterioration in salesclerks' conditions as employers squeezed their staffs to make ends meet. According to Lialich, the salesclerk has to acknowledge that employment in a store no longer resembles a "hotel where he is temporarily staying" until he can open his own store, but a "permanent residence" that he needs to maintain in good condition. Thus, Lialich argued, salesclerks must defend their interests as wage laborers. ${ }^{43}$

The existing salesclerks' organizations, aware that most shop assistants were disgruntled, paid close attention to the debate over the utility of mutual aid societies. Some responded by advocating significant reforms and concessions. In mid-March the five mutual aid societies met to discuss the following issues: establishment of a pension fund financed by both employees and employers, introduction of an arbitration court to settle labor disputes, limitation of child labor in stores, and institution of political reforms, particularly freedom to assemble, form unions, and strike. The proposals for an arbitration court and civil rights generated more opposition than did the others, but the conference ended with the representatives supporting all four proposals. As one delegate stated, the suggested reforms, particularly the establishment of an arbitration procedure, possess "moral significance which, by placing moral responsibilities on employers and employees, frees them of . . . unnecessary and tiring judicial red tape." ${ }^{44}$

41. Lupinskii, "Soiuz prikazchikov Odessy," 74; Bonnell, Roots of Rebellion, 161.

42. Iuzhnoe obozrenie, no. 2802, 10 April 1905.

43. Kommercheskaia Rossiia, nos. 156, 13 July 1905; 160, 17 July 1905; and 172, 31 July 1905. Gudvan, in Ocherki po istorii dvizheniia sluzhashchikh v Rossii, 85-86, makes a similar point.

44. Iuzhnoe obozrenie, no. 2785, 23 March 1905. 
The conferees also advocated ending all residency restrictions and legal disabilities of Jews to reduce competition among sales-clerical personnel in the Pale of Settlement as well as to enhance employment opportunities. ${ }^{45}$

Mutual aid society representatives who attended a government commission created to address salesclerks' problems also displayed reformist tendencies. In early 1905 Assistant Minister of Finance V. I. Timiriazev asked salesclerks' and office workers' mutual benefit societies to select delegates to a commission investigating the normalization of the workday in retail stores, warehouses, and offices. Standardizing the workday for salesclerks had been discussed on the local and national levels since the turn of the century, but little substantive progress had resulted. Now, in the open political arena after Bloody Sunday, any discussion of salesclerks' working conditions was guaranteed to bring up a host of economic and political issues.

As early as April, when news of the planned conference first reached Odessa, the OMASJS considered not sending a delegate to the commission. Citing the tsar's February 18 pronouncements ${ }^{46}$ and reacting to reform pressure within its own ranks, the organization's leaders asserted that "the fundamental reconstruction" of the government on the basis of popular representation and civil and political liberties was necessary to improve salesclerks' conditions. They did not expect that the Timiriazev Commission would improve the lot of Jewish salesclerks. They called for the end of discriminatory legislation against Jews and supported self-determination of all nationalities. ${ }^{47}$ In the end, however, the Jewish salesclerks agreed to send one delegate. Representatives of Christian salesclerks in Odessa also debated the merits of the Timiriazev Commission. Like their Jewish counterparts, members of the Mutual Aid Society of Christian Salesclerks argued that "the only guarantee for better working conditions for salesclerks is freedom of strikes, person, and assembly." 48

The conference, which convened in late May, was marked from the start by dissension and disagreement among representatives from provincial zemstvos, stock exchanges, the merchantry of Moscow and St. Petersburg, and mutual aid societies from all over the empire. Timiriazev wanted to limit the discussion to the length of the workday, but most representatives sought to include other issues, such as paid vacations; severance and sick pay; pensions; establishment of arbitration procedures; freedom to assemble, to form unions, and to strike; and the end of discriminatory legislation against Jewish salesclerks. The delegates argued that only discussing the length of the workday would not serve the overall interests of salesclerks and criticized the conference because its decisions were not binding upon the government. The majority of salesclerks' representatives, including I. N. Tiurin of Odessa's Mutual Aid Society of Christian Salesclerks, walked out of the conference and issued a call for the immediate election of people's representatives to reorganize "our entire legal order" and improve salesclerks' standards of living. Condemning as futile all efforts to address salesclerks'

45. Kommercheskaia Rossiia, no. 82, 28 March 1905.

46. They were referring to the imperial ukase and rescript that declared that Russians had the right to send the tsar proposals "for improving the public well-being" and expressed the government's intention to convene a national representative assembly enjoying consultative powers in the legislative process. For information on the ukase and rescript, see Sidney Harcave, The Russian Revolution of 1905 (London: CollierMacmillan, 1970), 129-130, and Abraham Ascher, The Revolution of 1905: Russia in Disarray (Stanford, Calif.: Stanford University Press, 1988), 112-113.

47. Voskhod, no. 22, 2 June 1905, 20; Iuzhnye zapiski, no. 24, 12 June 1905, 28-30; Iuzhnoe obozrenie, no. 2822, 3 May 1905.

48. Kommercheskaia Rossiia, no. 74, 19 March 1905. 
problems through bureaucratic channels, these representatives vowed to participate in only those commissions established by popular election. ${ }^{49}$

Unimpressed with the planned conference, salesclerks had, in April, formed a new mutual aid society (the Society of Employees in Commercial and Industrial Enterprises) under the leadership of Gudvan..$^{50}$ The city governor Dmitrii Neidhardt sanctioned it and nearly 1,000 Jewish and non-Jewish salesclerks joined. The initiation fees and membership dues were substantially lower than those charged by existing organizations and well within the means of most salesclerks, including women, who were allowed to join. ${ }^{51}$ The establishment of an organization including Jews and gentiles marked a break with past practice. Given what we know about the general tenor of ethnic relations in Odessa and the relative isolation of Jewish from Christian workers, the organizers' decision to bridge this ethnic separateness is significant.

Nonetheless, radical salesclerks, somewhat later, called the new organization "a still birth" because of the local authorities' approval and condemned it for its insufficiently proletarian objectives and for not defending workers' interests, particularly when it came to hours and days off. ${ }^{52}$ Defenders of the organization hoped to prevent such criticism by emphasizing that "the interests of salesclerks and employers are antagonistic, and in the name of liberation from exploitation salesclerks are uniting." 53

The criticism of the new organization was not entirely fair. The Society of Employees in Commercial and Industrial Enterprises did retain the traditional focus of mutual benefit societies: the promotion of the "material and moral" interests of salesclerks, such as providing legal advice, sickness and death benefits, and low-cost consumer goods. Many of the fledgling trade unions that emerged during 1905, however, expressed similar aims and pursued philanthropic concerns along with striking and collective bargaining. The new salesclerks' association did establish an arbitration bureau to regulate relations between employers and employees and created a fund to assist shop assistants in "partial and general strikes." It also called for establishment of contacts with the Union of Unions and other salesclerk organizations in Russia. While available sources do not agree on whether employers were excluded from the new organization, some evidence suggests that only shop assistants were eligible for full membership and "those persons rendering assistance" could be corresponding members, though they, as in the old organization, could apparently still hold office and vote..$^{54}$

The emergence of the new society highlights the extent to which one stratum of the Odessa work force had become frustrated with existing institutional arrangements and

49. Otchet pravleniia obshchestva vzaimnago vspomozhenia prikazchikov g. Odessy za 1905-1906 gody (Odessa, 1907), 83-90; Iuzhnye zapiski, no. 24, 12 June 1905.

50. Some confusion exists regarding the organization's name. Some accounts refer to it a a union; others call it a mutual aid society. Since it was renamed a union in late 1905 , it probably more closely resembled a mutual aid society than a trade union when it was formed. See Iuzhnoe obozrenie, no. 2813, 23 April 1905; Kommercheskaia Rossiia, nos. 97, 21 April 1905, and 98, 22 April 1905; Kontorshchik, no. 1, 5 January 1906; Golos prikazchika, no. 2, 23 April 1906, 9; Odesskie novosti, no. 6626, 23 April 1905.

51. Monthly dues to the new organization were 25 kopecks, with an initiation fee of 2 rubles. The OMASJS had a 5 ruble membership fee and monthly dues of about 1 ruble. See Kommercheskaia Rossiia, no. 11, 13 January 1905; Iuzhnoe obozrenie, no. 2813, 23 April 1905.

52. Golos prikazchika, no. 2, 23 April 1906, 9.

53. Odesskie novosti, no. 6626, 23 April 1905.

54. Golos prikazchika, no. 2, 23 April 1906, 9-10; Iuzhnoe obozrenie, no. 2810, 20 April 1905; Kommercheskaia Rossiia, nos. 97, 21 April 1905, and 98, 22 April 1905; Kontorshchik, no. 1, 5 January 1906, 9; Odesskie novosti, no. 6626, 23 April 1905; Zhizn' prikazchikov, no. 3, 16 December 1906. 
was seeking new avenues for improving working conditions and asserting control over their organization. Salesclerks had begun to break with the institutional legacy of mutual aid, especially in their readiness to strike. In the process they were expressing the urge for rights of citizenship characteristic of the opposition movement in 1905. In the words of Mayor P. A. Zelenyi, who addressed the opening session of the new organization, Odessa's salesclerks were setting an example for other workers by "democratizing" mutual aid in Odessa and demonstrating that the populace of Odessa was socially active and "fully worthy to receive rights of full citizenship" that would transform city government into "a forum for all citizens of all classes." ${ }_{55}$

The new organizational activism of Odessa salesclerks did not stem from a resurgent strike movement. On the contrary, shop assistants had rarely engaged in work actions of any sort during the first several months of 1905. The impetus for the dispute over the nature and objective of salesclerk organizations came from the failure of existing associations to address the pressing needs of the mass of shop assistants in Odessa and drew sustenance from the hothouse political atmosphere that attracted workers seeking alternative means of redressing their grievances, including the establishment of class-conscious socialist trade unions. Still, a full-fledged trade union of salesclerks did not emerge in Odessa until November. By then, shop assistants, who had joined most other workers in Odessa in massive walkouts in May-June and October, had pursued a course of action similar to that taken by other workers. After the October Manifesto, during the so-called Days of Freedom, shop assistants formed a Union of Salesclerks in November and the more-skilled and better-paid bookkeepers, officeworkers, and clerks established their own union in December after first being invited to join the Union of Salesclerks. Only shop assistants over age 17 (regardless of sex, nationality, religion, or political views) were entitled to full membership and the explicit aim of the union was to struggle "for the improvement of the economic and legal conditions of salesclerks," with strikes as the chief tactic. As had happened in the spring, activist salesclerks delivered speeches and wrote letters to Kommercheskaia Rossiia about rights of citizenship, political liberation, proletarian solidarity, and the struggle against capitalist exploitation. One salesclerk, displaying his grasp of the direct connection between political emancipation and economic welfare wrote that as union members "we shall discuss issues that concern us . . . first of all as citizens and then as salesclerks." "56

The Union of Salesclerks struck a serious blow to its major competitors, the OMASJS and the Society of Employees in Commercial and Industrial Enterprises. Shop assistants, evidently confident that they could extract economic concessions from their employers, preferred the adversarial employer-employee relationship of a trade union, which held out a sense of greater possibility and promise than did mutual aid societies. Thousands of shop assistants jammed the auditoriums in November to listen to, and even participate in, discussions concerning the establishment of a union. Even though only two hundred saw fit to pay membership fees and initial dues, membership

55. Iuzhnoe obozrenie, no. 2813, 23 April 1905; Kommercheskaia Rossiia, no. 98, 22 April 1905.

56. The charter of the Union of Salesclerks can be found in Kommercheskaia Rossiia, no. 261, 25 November 1905. It is reprinted in Lupinskii, "Soiuz prikazchikov Odessy," 91-92. The quotation is from Kommercheskaia Rossiia, no. 254, 17 November 1905; for other accounts of the formation of the union, see Kommercheskaia Rossiia, nos. 247, 9 November 1905; 249, 11 November 1905; 250, 12 November 1903; 257, 20 November 1905; 259, 23 November 1905; 261, 25 November 1905; 262, 26 November 1905; and 264, 29 November 1905; Iuzhnoe obozrenie, no. 2975, 24 November 1905; M. Dzhervis, "Professional'noe dvizhenie v Odesse v 1905 godu," Vestnik truda, no. 6(55) (1925), 258-259. 
rolls, as Bonnell reminds us, provide only one indicator of workers' attitudes toward the organized labor movement and the influence of unions on their constituencies. ${ }^{57}$ Government repression forced the Union of Salesclerks underground in December, but the flicker of organization and commitment to unionism remained alive. The 4 March 1906 law legalizing trade unions rekindled the union, and membership grew to some 1,800 persons by the fall of 1906 , making it a substantial union for Odessa and the empire as a whole. In the middle of 1906 the union conducted a successful campaign of strikes and other tactics against a wide range of retail stores and won concessions for its members in length of work day, Sunday rest, wages, severance pay, and vacation. Two important gains were the right to sit and read when there were no customers in the store and promises of polite address and treatment from employers. Many labor conflicts were settled by arbitration boards set up jointly by employers and workers, a far cry from the patient wait and see attitude of the mutual aid societies before $1905 .^{58}$

The OMASJS and the Society of Employees in Commercial and Industrial Enterprises atrophied and withered; the latter organization actually had vanished by 1907 . In November 1905 the Society of Employees in Commercial and Industrial Enterprises, under the leadership of Gudvan, renamed itself a union and made plans to hold a general meeting of all members for new elections to the board of directors. The society, however, lost its momentum to the rival union, which had formally dissociated itself from the mutual aid society (despite the fact that the charter of the Society of Employees in Commercial and Industrial Enterprises displayed marked resemblance to that drawn up by the Union of Salesclerks). The society declined steadily as most salesclerks came to support the Union of Salesclerks. In June 1906 the society chose Gudvan, who was simultaneously serving on the board of directors of the Union of Salesclerks, as their delegate to the Third All-Russian Congress of Mutual Aid Societies of Salesclerks; there he supported the congress's resolution that mutual aid societies merge with trade unions. Soon after, the society decided to liquidate itself and transfer its capital to either the union of salesclerks or the union of office workers. The transfer of funds occurred somewhat later when the city governor released the funds, which were then divided equally among the mutual aid societies of Jewish and Christian salesclerks. ${ }^{59}$

The OMASJS enjoyed a better fate, though it too felt the strain of competition with the Union of Salesclerks until the latter organization, which had several Social Democrats in responsible posts, fell prey to government reprisals and repression during 1907 and $1908 .^{60}$ The association tried to make itself accessible to the mass of salesclerks by implementing structural reforms. First, in December the organization expelled former city governor Neidhardt, who was accused by many residents of unleashing the October pogrom. ${ }^{61}$ Second and more important, beginning in 1906 the governing board

57. Bonnell, Roots of Rebellion, 136.

58. "Osvobozhdenie truda": Sbornik statei po rabochemu voprosu (Odessa, 1907), 113-116; Rabochee delo, no. 1, 15 August 1906, 15-16; Bonnell, Roots of Rebellion, 136; Lupinskii, "Soiuz prikazchikov Odessy," 69-72.

59. Lupinskii, "Soiuz prikazchikov Odessy," 70, 74-75, and 92; Protokoly 3-go vserossiiskago $s^{\prime \prime}$ ezda obshchestv vspomozheniia chastnomu sluzhebnomu trudu i drugikh odnorodnykh po idee $i$ tseli (Moscow, 1906), viii-xi, 6-7 and 177-179. Zhizn' prikazchikov, no. 3, 16 December 1906, reports that the liquidation occurred in the summer of 1906, but Lupinskii ("Soiuz prikazchikov Odessy," 75, citing archival documents) states that the decision to liquidate did not occur until mid-1907.

60. Lupinskii, "Soiuz prikazchikov Odessy," 67, 70, and 75-84.

61. Neidhardt had been dismissed as city governor soon after the October pogrom and no longer lived in Odessa in December (Iuzhnoe obozrenie, no. 2990, 19 December 1905). 
reduced members' fees, surveyed salesclerks about their needs and wants, and even began to mediate conflicts between store owners and salesclerks. A new charter making the organization more democratic and responsive to the needs of its constituency was not approved until 1913, evidently because conservative members blocked the reforms implemented by the progressive members, who had captured control of the board of governors in $1906 .{ }^{62}$ Consequently, the OMASJS did not attract the attention or support of most salesclerks, largely because it could not shake its deserved reputation as an organization that failed to represent the interests of rank and file salesclerks. Most shop assistants, having tasted the benefits of unionism, no matter how short-lived, were reluctant to return to mutual aid societies.

Workers in the Russian Empire followed many paths to unionization in 1905. The actual process of radicalization and political mobilization is difficult to flesh out, but available material permits us to draw the following conclusions: The organizational roots of the Union of Salesclerks can be found in the religious institutions of the Jewish community in late imperial Russia and in the secular organizations established by workers under a paternalistic government hesitant to adopt the labor management policies and practices found in western Europe and the United States. The route to unionism taken by salesclerks in Odessa (as well as by most workers in the empire) was not direct and was mediated by two developments: the failure of existing institutions and policies to safeguard the welfare of those workers they purported to protect and the political crisis that shook autocratic rule in 1905. By turning their backs on mutual aid societies, salesclerks expressed their disillusionment with the contemporary social and economic order at the same time as they embraced radical political solutions to their problems.

62. Ocherk deiatel'nosti Odesskago obshchestva vzaimnago vspomoshchestvovaniia prikazchikovevreev za 50 let, 18 and 30; Otchet pravleniia obshchestva prikazchikov-evreev za $1907 \mathrm{~g}$. (Odessa, 1908), vi-vii; Iuzhnoe obozrenie, nos. 3099, 16 May 1906; 3102, 19 May 1906; 3103, 20 May 1906; 3104, 21 May 1906; and 3105, 24 May 1906; Odesskie novosti, nos. 6934, 21 May 1906; and 7062, 24 October 1906. 